Akreditasi KEMENRISTEKDIKTI, Nomor: 28/E/KPT/2019
http://iurnal.stkippersada.ac.id/jurnal/index.php/VOX

\title{
PENERAPAN STRATEGI METAKOGNISI TERHADAP HASIL BELAJAR KOGNITIF SISWA PADA MATERI SUHU DI KELAS VII SMP NEGERI 3 SATU ATAP BALAI
}

\author{
Ivana Evivania $^{1}$, Anita ${ }^{2}$, \& Ira Nofita Sari ${ }^{3}$ \\ ${ }^{1,2,3}$ Pendidikan Fisika, IKIP PGRI Pontianak
}

Email: ivanaevivania77@gmail.com,anitaummufaqih@gmail.com,iranofitasari87@gmail.com

INFO ARTIKEL
Riwayat Artikel:
$\begin{array}{ll}\text { Menerima } & : 22 \text { Nopember } 2019 \\ \text { Revisi } & : 16 \text { April } 2020 \\ \text { Diterima } & : 28 \text { April } 2020\end{array}$

Kata Kunci:

Strategi Metakognisi, Suhu, Hasil Belajar

\begin{abstract}
ABSTRAK
Tujuan penelitian ini adalah untuk mengetahui bagaimana pengaruh penerapan strategi metakognisi terhadap hasil belajar siswa pada materi suhu di kelas VII SMP Negeri 3 Satu Atap Balai. Populasi dalam penelitian ini adalah seluruh siswa kelas VII SMP Negeri 3 Satu Atap Balai yang terdiri dari dua kelas yaitu kelas VII A dan kelas VII B. Adapun sampel penelitian ini adalah siswa kelas VII A sebagai kelas eksperimen berjumlah 29 siswa dan kelas VII B sebagai kelas kontrol berjumlah 29 siswa yang dipilih dengan teknik cluster random sampling. Teknik pengumpulan data yang digunakan adalah teknik pengukuran. Teknik analisis data yang digunakan dalam penelitian ini adalah analisis data kuantitatif. Alat pengumpulan data adalah tes posstest yang berbentuk essay. Berdasarkan dari hasil pengolahan data diperoleh rata-rata hasil belajar siswa data posstest sebesar 70,52 pengujian hipotesis dengan uji -test independent sample dengan $\alpha=5 \%$ diperoleh $Z_{\text {hitung }}=0,000$ dan $Z_{\text {tabel }}=0,05$ maka Ha diterima. Hal ini bearti terdapat pengaruh strategi metakognisi terhadap hasil belajar siswa pada materi suhu di kelas VII SMP Negeri 3 Satu Atap Balai. Perhitungan effect size diperoleh sebesar 2,15 sehingga dapat disimpulkan bahwa strategi metakognisi berpengaruh terhadap hasil belajar siswa dengan kriteria tinggi.
\end{abstract}

\section{ABSTRACT}

The purpose of this study is to find out how the influence of the implementation of metacognition strategies on student learning outcomes in the temperature material in class VII SMP Negeri 3 Satu Atap Balai. The population in this study were all students of class VII SMP Negeri 3 Satu Atap Balai consisting of two classes, slass VII A and Class VII B The sample of this study was class class VII A as an experimental class totaling 29 students and class VII B as a control class totaling 29 students selected by cluster random sampling tecnique. The data collection tecnique used is the measurement technique. Data collection tools are posstest tests in the form of essays. Based on the results of data processing obtained an average student learning outcomes posstest data of 70,52 hypothesis testing with independent sample t-test with $\alpha=5 \%$ obtained $Z_{\text {hitung }}=0,000$ and $Z_{\text {tabel }}=0,05$ then $\mathrm{Ha}$ is accepted. This means that there is an influence of metakognition strategis on student learning outcomes in the tempereture material, in class VII SMP Negeri 3 Satu Ata Balai. The calculatoin of the effect size obtained by 2,15 can be concluded that the metakognition strategy affects the learning outcomes of students with high criteria.
Ivana Evivania

Pendidikan Fisika, IKIP PGRI

Pontianak

ivanaevivania77@gmail.com
(C)2019 LPPM STKIP PersadaKhatulistiwa Sintang

\section{PENDAHULUAN}

Pada dasarnya seseorang yang menempuh pendidikan akan memiliki pengetahuan dan keterampilan yang lebih baik. Pendidikan merupakan hal yang sangat penting bagi kehidupan seseorang untuk mengarahkan kehidupan yang lebih baik. Seiring dengan perkembangan pendidikan sekarang ini, masih banyak kejadian (fenomena) yang sangat tidak kondusif untuk mencapai pendidikan yang lebih baik. Hal tersebut dikarenakan sampai saat ini masih berfokus ceramah dan konvesional sebagai strategi belajar siswa. Oleh karena itu seiring dengan perkembangan ilmu dan teknologi tidak terlepas juga ilmu sains, guru seharusnya mempunyai inovasi dalam memilih 
strategi, model, metode dan media dalam pembelajaran terkhusus pada pelajaran fisika. Strategi yang tepat akan sangat membantu tercapainya keberhasilan belajar siswa. Dalam proses pembelajaran diperlukan interaksi peserta didik dengan pendidik dan sumber belajar pada suatu lingkungan belajar, untuk mencapai proses pembelajaran yang efektif maka pengajar harus mampu mewujudkan strategi mengajar yang tepat melalui strategi dan interaksi pembelajaran yang efektif dalam proses pembelajaran yang baik. Anita dan Assagaf (2019).

Salah satu pembelajaran yang sangat penting adalah Ilmu Pengetahuan Alam (IPA) yaitu fisika. Berdasarkan hasil wawancara dengan guru IPA SMP Negeri 3 Satu Atap Balai diperoleh informasi bahwa masih terdapat siswa yang kesulitan dalam memahami materi fisika khusunya pada materi suhu. Hal ini dapat dilihat dari dokumentasi data hasil nilai ulangan harian materi suhu dengan KMM 65. Rata-rata nilai ulangan harian materi suhu semester ganjil siswa kelas VII SMP Satu Atap Balai Tahun ajaran 2015/2016 kelas VII yaitu 57,67. Tahun ajaran 2016/2017 kelas VII yaitu 52,58. Tahun ajaran 2017/2018 kelas VII A yaitu 54,26,kelas VII B yaitu 58,75.

Berdasarkan hasil dokumentasi tersebut terlihat bahwa rata-rata nilai ulangan harian siswa hampir sama dan belum mencapai KKM yang ditetapkan yaitu 65 .

Berdasarkan informasi melalui wawancara dengan guru, siswa masih mengalami kesulitan dalam memahami materi suhu, bagian yang sulit dipahami oleh siswa adalah perbadingan skala pada termometer, menentukan skala dan mengkonversi satuan suhu dari berbagai skala. Berdasarkan uraian tersebut, diharapkan dengan menerapkan strategi metakognisi dapat meningkatkan hasil belajar siswa.

Siswa yang dikatakan sukses adalah siswa yang memiliki kemampuan mengetahui apa yang dapat dipelajari dan mengetahui cara yang terbaik dalam belajar untuk dirinya, kemampuan ini disebut dengan kemampuan metakognisi [2].

Metakognisi adalah kesadaran seseorang tentang proses kognitifnya atau proses pengaturan diri seseorang dalam belajarnya sehingga seorang individu tersebut mengetahui bagaimana dia belajar, kapan waktu yang tepat untuk belajar, strategi apa yang cocok digunakan untuk belajar sehingga apa yang dilakukan dapat terkontrol secara optimal. Nurmalasari,dkk., (2015).

Strategi metakognisi memiliki beberapa kelebihan diantaranya adalah dapat merubah siswa pasif menjadi siswa aktif dalam proses pembelajaran, siswa lebih mudah memahami materi dan bebas mengeluarkan pendapat serta adannya praktik langsung yang membuat siswa mudah memahami materi, meransang siswa untuk berpikir kritis terhadap suatu permasalahan. Khoiriah, (2015)

Sehingga strategi metakognisi inilah yang paling tepat diterapkan pada pembelajaran fisika dalam materi suhu. Berdasarkan uraian di atas, harapannya agar pembelajaran dapat mencapai tujuan dengan hasil belajar yang baik seperti yang direncanakan. Oleh karena itu maka peneliti akan menerapkan strategi 
metakognisi pada materi suhu di kelas VII SMP Negeri 3 Satu Atap Balai.

\section{METODE PENELITIAN}

Metode dalam penelitian ini adalah metode eksperimen. Metode eksperimen digunakan dalam penelitian ini karena sesuai dengan tujuan umum dari penelitian yaitu untuk mengetahui penerapan strategi metakognisi terhadap hasil belajar siswa pada materi suhu dikelas VII SMP Negeri 3 Satu Atap Balai. Bentuk penelitian yang digunakan adalah Quasi-Experimental Design dengan rancangan penelitian adalah Posstest-Only Control Design. Quasi-Experimental Design digunakan karena pada kenyataannya sulit mendapatkan kelompok kontrol yang digunakan untuk penelitian. Populasi dalam penelitian ini yaitu seluruh siswa kelas VII SMP Negeri 3 Satu Atap Balai yang terdiri dari dua kelas yakni kelas VII A sebagai kelas eksperimen berjumlah 29 siswa dan kelas VII B sebagai kelas kontrol berjumlah 29 siswa. Teknik yang digunakan dalam menentukan sampel penelitian yaitu dengan menggunakan teknik cluster random sampling melalui uji homogenitas populasi pada kelas VII A dan kelas VII B digunakan uji barlett dari nilai ulangan harian siswa sebelum materi suhu. Adapun hasil uji barlett yakni keputusan x2 hitung $<$ x2 tabel yaitu $0,1648<3,831$. Setelah di uji homogenitas dan dipilih secara acak sehingga terpilih kelas VII A sebagai kelas esperimen dan kelas VII B sebagai kelas kontrol. Setelah dilakukan pengumpulan data, data di analisis secara deskriptif dengan menggunakan persamaan rata-rata nilai siswa dengan tolak ukur rata-rata hasil belajar siswa (skala 0-100) pada Tabel 2 yang merujuk pada. Purwanto, (2013).

Tabel 2. Tolak Ukur Rata-rata Hasil Belajar Sisisa

\begin{tabular}{cc}
\hline Rata-rata & Kategori \\
\hline $90-100$ & Sangat Tinggi \\
$80-89$ & Tinggi \\
$65-79$ & Sedang \\
$55-64$ & Rendah \\
$0-54$ & Sangat Rendah \\
\hline
\end{tabular}

selain itu juga dilakukan analisis data melalui uji prasyarat yakni uji normalitas dan homogenitas. Uji hipotesis dengan menggunakan uji t-test independent sample. Analisis seberapa besar pengaruh penerapan strategi metakognisi terhadap hasil belajar siswa menggunakan uji effect size dengan kriteria Pada Tabel 3 yang merujuk pada. Subana dan Sudrajat, (2011)

Tabel 3. Kriteria Effect Size

\begin{tabular}{cc}
\hline Penilaian & Kriteria \\
\hline ES $\leq 0,20$ & Rendah \\
$0,20<\mathrm{ES} \leq 0,80$ & Cukup \\
ES $>0,80$ & Tinggi \\
\hline
\end{tabular}

\section{HASIL DAN PEMBAHASAN}

Pembelajaran IPA dalam penelitian ini dilaksanakan sebanyak 2 kali pertemuan tatap muka dengan durasi waku 4 jam (4×40 menit) untuk pembelajaran, 1 jam (40 menit) untuk mengerjakan soal posstest kelas eksperimen dan 1 jam (40 menit) untuk mengerjakan soal posstest kelas kontrol. Kelas eksperimen diberi perlakuan yaitu strategi metakognisi dan kelas kelas kontrol diberi perlakuan metode konvensional yaitu metode inkuiri hasil modifikasi guru. Pada kelas eksperimen di tahap pendahuluan guru memberikan apersepsi 
dengan mengajukan pertanyaan kepada siswa, "Pernahkah kamu berjalan di bawah sinar matahari yang terik? Bagaimana rasannya?". Siswa menjawab pertanyaan guru "pernah" yang dirasakan adalah panas. Kemudian guru bertanya lagi, jika kamu berada di dalam ruangan berAC? Bagaimana rasanya? siswa menjawab "dingin dan sejuk". Pada tahap ini siswa mampu berpikir aktif dalam menjawab pertanyaan guru sesuai dengan pengetahuan awal yang dimiliki oleh siswa, yang dibuktikan benarnya jawaban siswa dari pertanyaan guru pada apersepsi. Guru kemudian menyampaikan tujuan pembelajaran yang akan dicapai dalam kegiatan pembelajaran pada materi suhu.

Tahap Pertama mengidentifikasi, guru mendorong siswa untuk mengidentifikasi kemampuan diri sendiri tentang apa yang diketahui dan apa yang tidak diketahui melalui aktivitas pengamatan dan pertanyaan reflektif mengenai mengapa ketika tangan dicelupkan ke air panas, es dan air biasa ada perbedaan yang kita rasakan. Siswa dibagi ke dalam 6 kelompok yang terdiri dari 4 orang. Guru membagikan LKS kepada siswa, tiap siswa mendapatkan satu LKS. Guru meminta siswa untuk mempersiapkan alat dan bahan, kemudian guru memberikan pertanyaan kepada siswa "Apakah kalian pernah mencelupkan tangan kedalam air hangat, air dingin dan air biasa?" Siswa menjawab pernah. Guru mengarahkan siswa untuk menuliskan jawaban pada LKS yang telah diberikan.

Guru meminta siswa untuk mencelupkan tangan ke dalam air hangat, dingin dan biasa guru bertanya, apa yang dirasakan ketika tangan dicelupkan kedalam air hangat, dingin dan biasa? Mengapa ketika tangan dicelupkan ada perbedaan yang dirasakan? Siswa menjawab karena suhunya berbeda. Guru merespon hasil diskusi siswa dengan memberikan penegasan terhadap jawaban siswa (hasil diskusi), dari hasil demonstrasi tadi terjadi perbedaan yang kita rasakan ketika tangan dicelupkan kedalam air hangat, dingin dan biasa hal itu disebabkan karena adannya perubahan suhu. hasil jawaban siswa dapat dilihat pada Gambar 1.

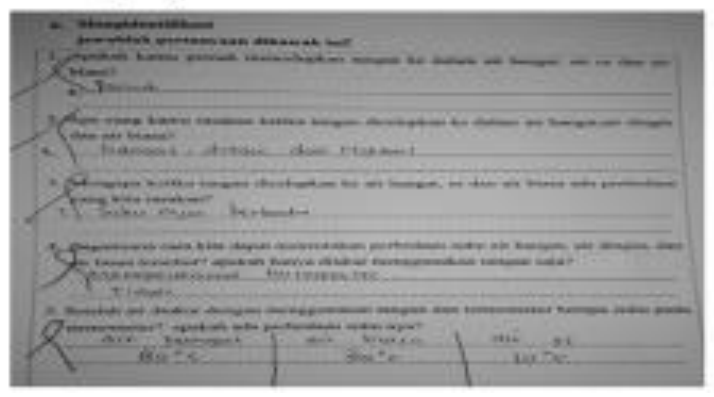

Gambar 1. Hasil Jawaban Siswa

Hasil demostrasi dan diskusi yang telah dilakukan di tahap mengidentifikasi sudah mampu mengidentifikasi dengan membuat keputusan dengan menuliskan jawaban sesuai dengan apa yang mereka ketahui dari permasalahan yang diberikan di awal yang dibuktikan dengan benarnya hasil jawaban siswa.

Tahap Kedua berbicara tentang berpikir (Talking About Thingking) yaitu guru mengarahkan siswa untuk berdiskusi tentang hasil identifikasi. Masing-masing satu orang siswa perwakilan dari tiap kelompok menyampaikan hasil identifikasi dan mendeskripsikan pendapatnya tentang pemecahan masalah dari pertanyaan yang telah disampaikan pada tahapan mengidentifikasi melalui LKS. 
Dengan diskusi siswa di dorong menggunakan pengetahuan dan pengalamnnya untuk memecahkan masalah, siswa mampu menyatakan pendapatnya sendiri secara lisan, dengan demikian siswa melatih diri untuk menyatakan pendapatnya sendiri secara lisan tentang suatu masalah bersama. Roestiyah, (2012).

Pada tahap berbicara tentang berpikir (Talking About Thingking) siswa sudah mampu mendeskripsikan proses berpikirnya melalui LKS, yang dibuktikan hasil pertanyaan lisan guru dengan pertanyaan di LKS jawaban lisan dengan jawaban di LKS hasilnya sama seperti pada Gambar 3.

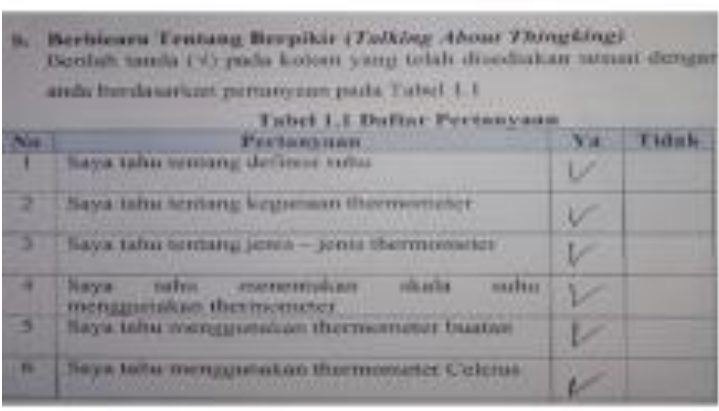

Gambar 3. Hasil Jawaban Siswa

Tahap Ketiga membuat jurnal belajar (keeping thingking journal), guru meminta siswa untuk membuat catatan terhadap hasil identifikasi dan diskusi melalui jurnal belajar ada LKS. Jurnal belajar pada kelas eksperimen digunakan sebagai catatan selama melakukan proses pembelajaran dengan strategi metakognisi. Komponen dalam jurnal belajar ini meliputi, perencanaan, monitoring dan catatan hasil identifikasi dan hasil diskusi. Pada kolom perencanaan, monitoring dan catatan hasil identifikasi dan hasil diskusi, siswa yang melakukan kegiatan ini di pertemuan kedua lebih baik dari pertemuan pertama. Faktor yang menyebabkan ini terjadi karena pada pertemuan pertama siswa belum memahami dengan baik instruksi yang diberikan oleh guru terkait apa yang harus dilakukan pada kolom perencanaan. Jurnal belajar siswa dapat dilihat seperti pada Gambar 4, 5 dan 6.

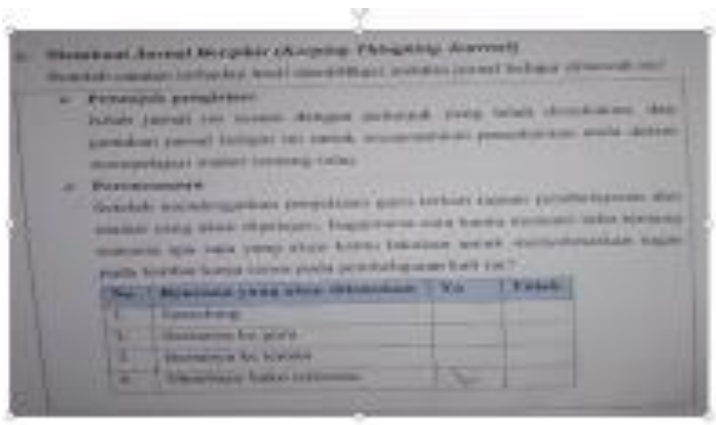

Gambar 4. Kolom Perencanaan

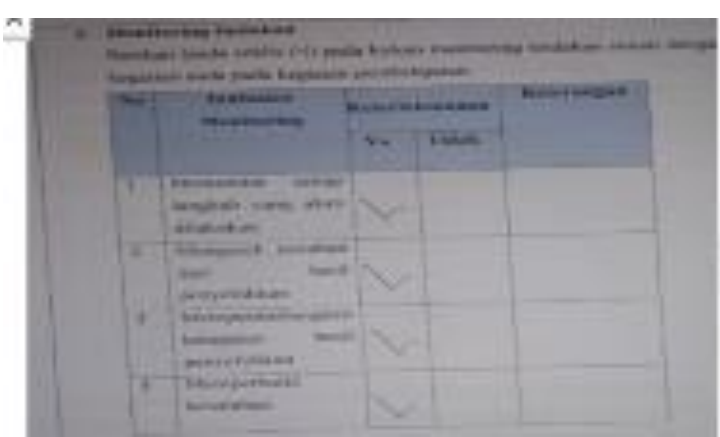

Gambar 5. Kolom Monitoring

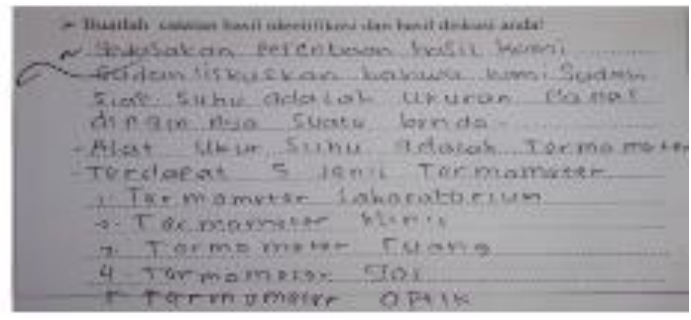

Gambar 6. Kolom Catatan Hasil Identifikasi

Pada tahap ini siswa sudah mampu membuat jurnal berpikir yang dibuktikan dari jawaban lisan yang dijawab siswa pada tahap ini sejalan dengan hasil pengerjaan LKS siswa pada kolom perencanaan, monitoring dan catatan hasil identifikasi dan hasil diskusi.

Tahap Keempat membuat perencanaan dan regulasi diri siswa secara berkelompok 
menyiapkan alat dan bahan percobaan tentang membandingkan hasil pengukuran termometer buatan dengan termometer laboratorium berdasarkan langkah kerja pada LKS. Pada tahap membuat perencanaan dan regulasi diri dipertemuan pertama siswa masih diarahkan oleh guru untuk menentukan alat dan bahan yang akan digunakan sesuai percobaan dan dipertemuan kedua siswa sudah mampu membuat perencanaan dan regulasi diri seperti pada Gambar 7.

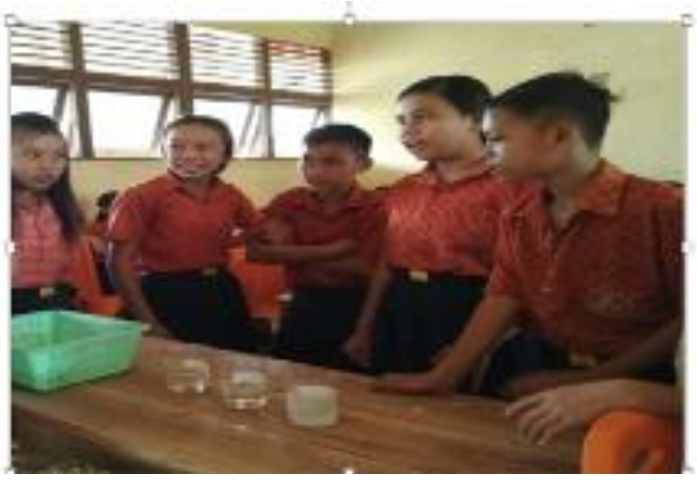

Gambar 7. Siswa menyiapkan alat dan bahan percobaan

Tahap Kelima melaporkan kembali proses berpikir (debriefing thingking process) siswa melakukan percobaan berdasarkan prosedur/langkah kerja dan mengumpulkan data hasil percobaan melalui LKS yaitu membandingkan hasil pengukuran pada termometer buatan dengan termometer laboratorium. Pada tahap ini siswa melakukan percobaan sesuai prosedur/langkah kerja melalui LKS. Setelah melakukan percobaan siswa kemudian berdiskusi dengan kelompoknya dan mengumpulkan data dari hasil percobaan pada LKS seperti Gambar 8.

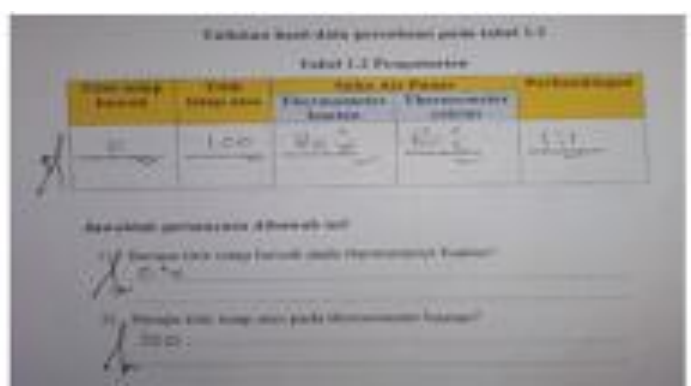

Gambar 8 Hasil Data Percobaan

Siswa melakukan suatu percobaan tentang suatu hal, mengamati prosesnya serta menuliskan hasil percobaannya, kemudian hasil pengamatan itu disampaikan ke kelas dan dievaluasi oleh guru yang bertujuan agar siswa mampu mencari dan menemukan sendiri berbagai jawaban atas persoalan-persoalan yang dihadapinnya dengan mengadakan percobaan sendiri, siswa terlatih dalam cara berpikir yang ilmiah (scientific thingking). Roestiyah, (2012)

Dengan eksperimen siswa menemukan bukti kebenaran dari teori sesuatu yang sedang dipelajarinnya. Pada tahap ini siswa sudah mampu melaporkan kembali proses berpikir yang dbuktikan benarnya jawaban siswa pada LKS.

Tahap Keenam evaluasi diri (self-evalution) guru membantu siswa untuk menilai kembali pemahaman diri mereka sendiri terhadap pembelajaran yang telah dilakukan serta memberikan penjelasan kembali kepada siswa yang belum paham. Evaluasi hasil belajar pembelajaran adalah suatu proses menentukan nilai prestasi belajar pembelajaran dengan menentukan patokan-patokan tertentu guna mencapai tujuan pengajaran yang telah ditentukan sebelumnnya. Suardi, (2018). 
Pada tahap ini siswa sudah mampu membuat kesimpulan terhadap pembelajaran yang telah dilaksanakan yang dibuktikan pada hasil LKS siswa seperti pada Gambar 9.

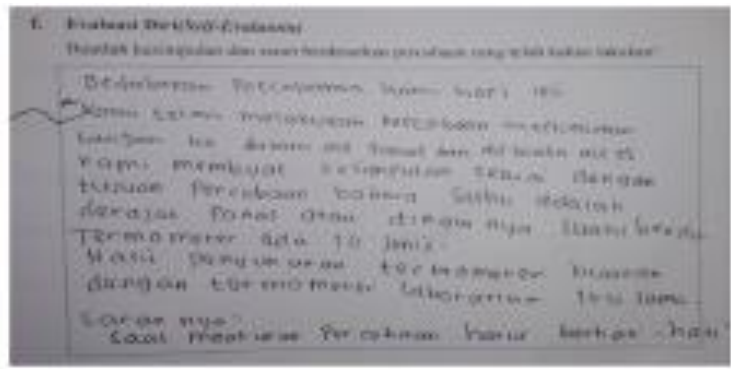

Gambar 9. Hasil Jawaban Siswa

Kelas kontrol yaitu diberi perlakuan dengan metode konvensional. Tahap pendahuluan guru menyampaikan tujuan pembelajaran kepada siswa. Kemudian guru menyajikan permasalahan berupa pertanyaan "mengapa ketika tangan dicelupkan kedalam air hangat, dingin dan biasa ada perbedaan yang dirasakan?". Siswa menjawab karena suhu air yang beda. Guru membagikan LKS kepada siswa, tiap siswa mendapatkan satu LKS. Guru meminta siswa untuk menuliskan dugaan sementara atau hipotesis terhadap masalah yang disajikan di LKS. Siswa menuliskan hipotesis seperti pada Gambar 10.

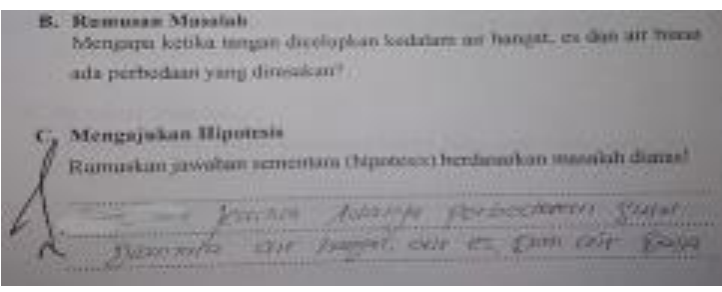

Gambar 10. Hasil Hipotesis Siswa

Pada tahap menuliskan hipotesis siswa mampu menuliskan hipotesis mereka berdasarkan rumusan masalah yang guru berikan di awal. Kemudian guru menjelaskan materi pembelajaran. Selanjutnya guru memberikan soal latihan kepada siswa, siswa mengerjakan soal latihan. Hasil kerja siswa dapat dilihat pada Gambar 11.

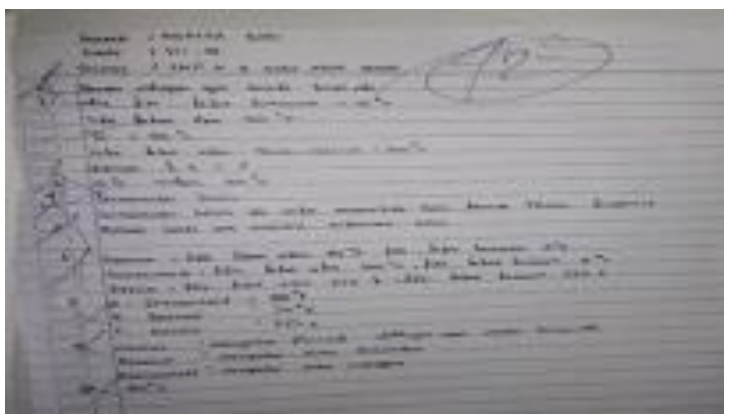

Gambar 11. Hasil Kerja Siswa

Setelah siswa mengerjakan soal ditahap akhir guru dan siswa bersama-sama membuat kesimpulan melalui kegiatan demonstrasi dan diskusi, siswa dapat menjelaskan definisi suhu dengan benar terhadap materi yang telah disampaikan.

Data nilai rata-rata siswa kelas kontrol sebesar 53,52 dengan standar deviasi 7,908. Nilai ratarata kelas eksperimen sebesar 70,52 dengan standarr deviasi 7,438. Perbedaan hasil belajar siswa dikelas kontrol dan eksperimen dikarenakan perlakuan yang berbeda yang menyebabkan hasil belajar siswa pada kelas eksperimen lebih baik dari pada kelas kontrol. Hasil pengujian hipotesis secara statistik parametris dengan menggunakan uji t-test independent sample dengan SPSS maka Ho di tolak atau $\mathrm{Ha}$ di terima, sehingga terdapat perbedaan hasil belajar siswa yang diajarkan dengan strategi metakognisi dan metode pembelajaran konvensional. Siswa yang diajarkan dengan strategi metakognisi lebih baik dari pada dengan metode pembelajaran konvensional pada materi suhu. Melalui penerapan tindakan yang mengacu pada pembelajaran strategi metakognisi, terdapat peningkatan hasil belajar siswa dalam 
pembelajaran fisika. Melalui proses metakognisi ini siswa dibimbing untuk berpikir kritis dan menetukan tingkah laku ketika siswa mencoba untuk memahami suatu keadaan dalam menyelesaikan masalah, dengan bantuan lembar kerja siswa (LKS).

Adanya praktik lansung yang membuat siswa lebih mudah memahami materi sehingga siswa bebas mengeluarkan pendapat serta meransang siswa untuk aktif dalam pembelajaran. Yongrim (2014).

Dengan praktek siswa akan lebih mudah mengaplikasikan materi yang diberikan oleh guru, siswa akan mampu membuktikan teori yang telah dia dapatkan setelah praktek.

Pada kelas eksperimen siswa di latih untuk melakukan langkah-langkah strategi metakognisi dimulai dari mengidentifikasi yaitu siswa diberikan permasalahan awal, kemudian siswa merespon sesuai dengan apa yang mereka ketahui. Pembelajaran dengan strategi metakognisi melatih dan mengajar siswa untuk belajar secara aktif dengan mengikuti tahaptahap pembelajarannya. Penerapan strategi metakognisi ini dapat membantu siswa untuk dapat memahami konsep suhu. Penerapan strategi ini sangat efektif menurut beberapa penelitian yang sudah lebih dulu menerapkannya.

Hasil penelitiannya adalah terdapat pengaruh yang signifikan, kelas eksperimen memiliki hasil belajar yang lebih baik dibandingkan dengan kelas kontrol. Khoiriah (2015).

Selanjutnya hasil penelitian bahwa penerapan strategi metakognisi sangat berpengaruh baik terhadap hasil belajar siswa. Putri, dkk (2012). Pendapat oleh peneliti di atas bahwa pada saat penelitian siswa yang mendapat penerapan strategi metakognisi lebih mudah dalam memahami materi pelajaran serta semua aktivitas belajar sehingga dapat dengan mudah mendapatkan pengetahuan. Pada kelas kontrol, rata-rata hasil belajar siswa setelah kegiatan pembelajaran belum optimal, hal ini dikarenakan siswa kurang semangat dalam mengikuti kegiatan pembelajaran terutama setelah separuh waktu kegiatan pembelajaran berlansung siswa merasa bosan karena siswa hanya mendengarkan penjelasan guru.

Perbedaan tahapan antara strategi metakognisi dengan metode konvensional dapat di lihat pada Tabel 4. 
Tabel 4. Perbedaan Tahapan antara Strategi Metakognisi dengan Metode Konvensional

\begin{tabular}{|c|c|c|c|}
\hline \multicolumn{2}{|c|}{ Strategi Metakognisi } & \multicolumn{2}{|c|}{ Metode Konvensional Guru } \\
\hline Tahapan & Deskripsi & Tahapan & Deskripsi \\
\hline Pendahuluan & $\begin{array}{l}\text { Pada tahapan strategi } \\
\text { metakognisi, guru } \\
\text { menyampaikan } \\
\text { pendahuluan kepada siswa } \\
\text { dengan menyiapkan siswa } \\
\text { untuk belajar (menyiapkan } \\
\text { buku, alat tulis) }\end{array}$ & Pendahuluan & $\begin{array}{lr}\text { Pada } & \text { tahapan } \\
\text { konvensional, Guru } \\
\text { menyampaikan } \\
\text { pendahuluan kepada } \\
\text { siswa } & \text { dengan } \\
\text { menyiapkan siswa } \\
\text { untuk } \\
\text { (menyiapkan buku, } \\
\text { alat tulis) }\end{array}$ \\
\hline Apersepsi & $\begin{array}{lr}\text { Guru } & \text { memberikan } \\
\text { apersepsi } & \text { dengan } \\
\text { mengajukan } & \text { pertanyaan" } \\
\text { pernahkah } & \text { kamu } \\
\text { berjalan dibawah sinar } \\
\text { matahari, } \\
\text { rasanya?" bagaimana }\end{array}$ & Apersepsi & - \\
\hline Penjelasan & 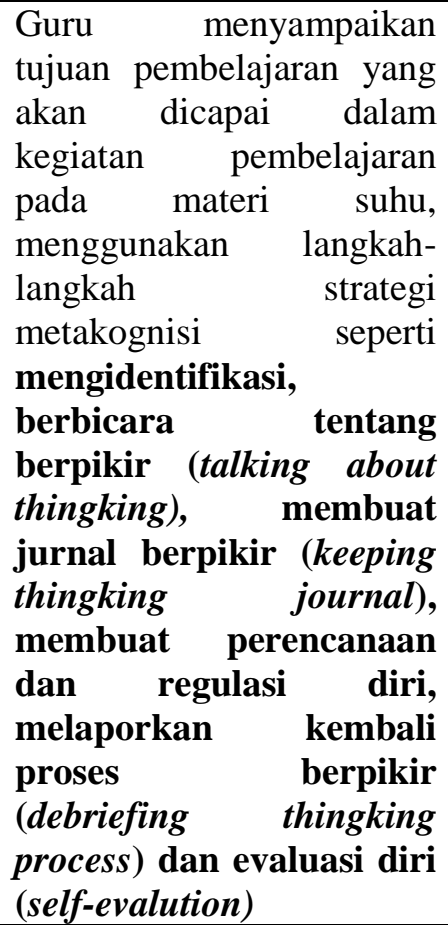 & Penjelasan & $\begin{array}{l}\text { Guru menyampaikan } \\
\text { tujuan pembelajaran } \\
\text { dan menjelaskan } \\
\text { materi pembelajaran } \\
\text { yaitu suhu }\end{array}$ \\
\hline LKS & $\begin{array}{l}\text { Siswa mengerjakan LKS } \\
\text { sesuai dengan langkah } \\
\text { kerja/percobaan. Siswa } \\
\text { melakukan percobaan } \\
\text { tentang mengukur suhu } \\
\text { air dingin, hangat, air } \\
\text { biasa dan } \\
\text { membandingkan hasil } \\
\text { pengukuran termometer } \\
\text { buatan dengan } \\
\text { termometer } \\
\text { laboratorium. }\end{array}$ & LKS & $\begin{array}{lr}\text { Siswa mengerjakan } \\
\text { LKS r dengan } \\
\text { menjawab hipotesis } \\
\text { dan membuat } \\
\text { kesimpulan } \\
\text { berdasarkan } \\
\text { permasalahan yang } \\
\text { guru berikan. }\end{array}$ \\
\hline
\end{tabular}


Perbedaan strategi metakognisi dalam proses pembelajaran dapat memperbaiki hasil belajar siswa. Pembelajaran strategi metakognisi dapat merubah siswa pasif menjadi siswa aktif dalam proses pembelajaran dan siswa lebih mudah memahami materi dan mengeluarkan pendapat, dengan adanya praktik lansung membuat siswa mudah memahami materi serta meransang siswa untuk berpikir kristis terhadap suatu permasalahan. Terdapat kedala dalam pertemuan pertama di kelas eksperimen yakni beberapa siswa tidak dapat menyelesaikan LKS secara optimal, hal ini dikarenakan siswa belum terbiasa mengerjakan LKS dan melakukan praktikum tentang suhu sebelumnya yang membuat waktu menjadi tidak efesien. Berdasarkan penjelasan di atas maka dapat di lihat bahwa pembelajaran menggunakan strategi metakognisi lebih efektif dibandingkan dengan pembelajaran konvensional. Hasil yang diperoleh adalah effect size sebesar 2,15 maka berdasarkan kriteria yang berlaku hal ini dibuktikan dengan effect size tergolong tinggi.

\section{SIMPULAN}

Berdasarkan uraian hasil penelitian di atas maka dapat disimpulkan bahwa penerapan strategi metakognisi berpengaruh terhadap hasil belajar siswa pada materi suhu di kelas VII SMP Negeri 3 Satu Atap Balai. Hasil belajar siswa tergolong gagal, rata-rata hasil belajar siswa setelah diterapkan metode konvensional yaitu sebesar 53,52 dengan standar deviasi 7,908. Hasil belajar siswa tergolong baik, rata-rata hasil belajar siswa setelah diterapkan strategi metakognisi yaitu sebesar 70,52 dengan standar deviasi 7,438. Hasil belajar siswa setelah diterapkan strategi metakognisi lebih baik dari pada metode konvensional. Besar pengaruh strategi metakognisi terhadap metode konvensional pada materi suhu dilihat dari hasil belajar siswa di kelas VII SMP Negeri 3 Satu Atap Balai tergolong tinggi yakni hasil perhitungan effect size yang diperoleh 2,15.

\section{DAFTAR RUJUKAN}

Anita \& Assagaf, S.L.H. 2019. Analisis Kemampuan Metakognisi Mahasiswa Calon Guru. VOX Edukasi 10 (1) 62.

Khoiriah, T. 2015. Pengaruh Strategi Belajar Metakognisi Terhadap Hasil Belajar Siswa pada Konsep Sistem Pencernaan pada Manusia. Fakultas Ilmu Tabiyah dan Keguruan (FITK) Jakarta: Tidak diterbitkan.

Nurmalasari, RL.,dkk. 2015. Pengaruh Kemampuan Metakognisi Terhadap Hasil Belajar Matematika di SMP Negeri 2 Leuwimunding Kabupaten Majalengka. Jurnal Nusantara Of Research ,2(2), 133-147.

Purwanto, Ngalim. 2013. Prinsip-Prinsip dan Teknik Evaluasi Pengajaran. Bandung: PT Remaja Rosdakarya.

Putri, AW., dkk. 2012. Pengaruh Penerapan Strategi Metakognitif dalam Metode Inkuiri Terhadap Hasil Belajar. Unnes Jurnal Of Biology Education. 1 (3), 266271.

Roestiyah, N, K. 2012. Strategi Belajar Mengajar. Jakarta: PT Asdi Mahasatya.

Suardi, S. 2018. Belajar Dan Pembelajaran. Yogyakarta: Penerbit Para Ilmu.

Subana, M., \& Sudrajat. 2011. Dasar-dasar Penelitian Ilmiah. Bandung: CV Pustaka Setia

Yongrim. 2014. Metode Praktik Lansung. 